\title{
Empowering Nigerian Youth for Peace-building and Nonviolent Action
}

\author{
Mariya Shuaibu Suleiman \\ The Peace Gong Coordinator, Nigeria \\ Corresponding author: mariashuaibu234@gmail.com
}

Received: 12 Jan., 2019

Revised: 03 Apr., 2019

Accepted: 28 May, 2019

\begin{abstract}
Conflicts and violence are now a global challenge. There is increasing necessity to ensure participation of all sections of the society to contribute to peace in communities across the world. It is not just the job of governments or institutions but all individuals. Given the huge youth population, young people have a pivotal role to play in peace processes. In the backdrop of wide diversity of Nigerian society, the youth can play both a violent and nonviolent role. The challenge is to empower them so that they can contribute to peace works and nonviolent action. This article captures perspectives of large number of young people on what they think are the core elements that youth should imbibe and learn so as to become more effective peace-builders.
\end{abstract}

Keywords: Youth as peace-builders, nonviolent action, tolerance, acceptance, forgiveness

Conflicts and violence are a global challenge today. Tension, reduced tolerance and disrespect for human rights have become a world-wide phenomenon. This was aptly captured by the former UN Secretary General Kofi Annan in his Nobel Peace Prize acceptance speech in 2001 who said, "We have entered the third millennium through a gate of fire. .... New threats make no distinction between races, nations or regions. A new insecurity has entered every mind, regardless of wealth or status....In the early beginnings of the 21st century - a century already violently disabused of any hopes that progress towards global peace and prosperity is inevitable -- this new reality can no longer be ignored. It must be confronted....The 20th century was perhaps the deadliest in human history, devastated by innumerable conflicts, untold suffering, and unimaginable crimes. Time after time, a group or a nation inflicted extreme violence on another, often driven by irrational hatred and suspicion, or unbounded arrogance and thirst for power and resources... Peace must be made real and tangible in the daily existence of every individual in need. Peace must be sought, above all, because it is the condition for every member of the human family to live a life of dignity and security."

As Kofi Annan underlined on the need to make 'peace real and tangible in the daily existence of every individual in need', the challenge for every society is to work continuously for sustainable and just peace. Increasingly several scholars and practitioners have been stressing on the participation of different sections of the society for achieving tangible peace. A critical section of the population which needs to be nurtured and empowered to contribute to peacebuilding is the youth. More than ever before, in the fast-changing global scenario, the role of youth to contribute to peace and nonviolent action has become critical. 
This article looks at different dimensions of youth participation and how they need to be empowered so that they can contribute towards a peaceful society and nonviolent action in the context of Nigeria. The Preamble to the Constitution of UNESCO points out, "Since war begins in the minds of men, it is in the minds of men that defenses of peace must be constructed." Hence the objective of youth participation is how we promote peace orientation amongst young people so that they can contribute towards a culture of peace.

\section{Encouraging young Nigerians}

Peace is the wholeness created by right relationships with oneself, other persons, other cultures, other life, Earth, and the larger whole of which all are a part. - The Earth Charter 2000

UNESCO (2013) notes, "Peace should never be taken for granted. It is an on-going process, a long-term goal which requires constant engineering, vigilance and active participation by all individuals. It is a choice to be made on each situation, an everyday life decision to engage in sincere dialogue with other individuals and communities, whether they live a block or a click away."

It is clear that peace can never be a one-time goal and it is a continuous endeavor to sincerely work to achieve peace in our communities. In the backdrop of emerging conflicts, the horizons of peace are also expanding. For instance, John Paul Lederach (2005) talked about the concept of just peace which he described as a dynamic social construct that entails approaches which reduce violence and destructive cycles of social interaction and at the same time increase justice in any human relationship.

In the context of wide-ranging horizons of peace, it is important to understand on the importance of interventions at different levels. Here again Lederach's (1998) pyramid of conflict gives us the direction on how peace work could be carried out. He says it can be carried out 'at the grassroots, the leaders and the middle level creating a genuine sense of participation, responsibility, and ownership in the process across a broad spectrum of the population'. For achieving just and sustainable peace, all stakeholders will have to constantly interact with each other across all levels. It is here right from the grassroots to middle level and even at the leadership level, the role of young people in contributing to peace work is critical. It is true for all societies across the world including Nigeria, one of the most developing countries of Africa.

Nigeria is blessed with diverse group of people, tribes, languages, religions and cultures. It has about 250 languages, 774 local governments and 36 states and the federal capital territory, Abuja. Even though, there have been cases of conflicts, bomb blasts, tribalism and ethnic differences but Nigerian have still tried to maintain the peace code of togetherness and unity in diversity. Conflict is everywhere and it is inevitable. Conflict is never been a choice, it just happens. It is on the ingenuity of the people of a community how perseverant they are and how they manage to resolve conflicts through nonviolent means.

The youth of Nigeria have a critical role to play to contribute peace works. Leo Buscaglia has aptly said, "Don't spend your precious time asking 'Why isn't the world a better place?' It will only be time wasted. The question to ask is 'How can I make it better? To that there is an answer." It is with this philosophy that the youth of Nigeria need to act to ensure a culture of peace.

In Nigerian society, we have violence at different levels right from direct, indirect and structural violence. Violence could mean not going to school or colleges, staying indoors 24 hours, no good food, not playing games of any kind, mosques and churches being closed and shutdown of markets. It would also mean that all universal freedom is restricted, curfew all day and abuse of human rights. It means depression, anxiety, trauma, sorrow, hate, tribalism, segregation, discrimination among others.

But we must remember what Gandhi had said, "You must not lose faith in humanity. Humanity is an ocean; if a few drops of the ocean are dirty, the ocean does not become dirty." Inspite of violence the challenge before the young people is to shape their efforts for peace-building and not lose hope. 
A study by the United Nations Development Programme (UNDP) Bureau for Crisis Prevention and Recovery (2005:9) states that:

There is an automatic tendency to problematise youth as a factor in violent conflict while overlooking their many positive contributions to a society, including their potential role in sustaining the social fabric and peace, as well as their survival in impossible environments.

In the context of Nigeria, in 2017, Search for Common Ground (Search) conducted qualitative research with young women and men in five countries to support data collection for the United Nations Secretary-General's Progress Study on Youth, Peace and Security, mandated by Security Council Resolution 2250. The objective was to document young people's experiences and contributions to peace and security, as well as provide a platform for them to share their concerns, recommendations and solutions on how to enhance these contributions and their engagement in the consolidation of peace.

The Search for Common Ground (2017) report on consultations with youth of Nigeria points out, "Young people call on government, security agencies and community leaders to adopt more responsive, responsible, and collaborative approaches for working with young people. They also emphasize the need for increasing services to internally displaced persons, including creating the conditions for their return home, and creating opportunities for positively engaging vigilante groups and members of the Civilian Joint Task Force. Another key message is to recognize and support the work that young people are doing in extremely difficult situations to build peace, counter violent extremism, provide security and emergency relief."

The report further points out, "Young women and young men feel unheard, isolated and marginalized. In an increasingly connected world, they are disconnected from other youth, their communities, and main channels of action, and express a deep need to belong....Youth demand greater inclusion at all levels- community, traditional, government, state institutions."
The report also extensively delved on the participation of young women in peace works. It noted, "Patriarchal norms, cultural beliefs, insecurity and gender-based violence severely limit young women's safety, mobility, and access to the public sphere, including their ability to voice ideas and concerns, realize their aspirations, and participate in peacebuilding. Recommendations include: raising awareness and celebrating young women's contributions; engaging families to obtain their approval and trust; and developing community support systems to promote participation and ensure safety in organizations and while traveling to/from activities. Another recommendation was the need to engage and educate men and boys about the diverse and constructive roles young girls and young women play in their communities."

An important aspect of youth participation in peacebuilding highlighted by the Search for Common Ground Report was the issue of accessibility to spaces. It pointed out, "In response to violence and loneliness, youth need access to spaces where they can feel valued and explore their aspirations. This includes spaces where young men are supported in expressing vulnerability. Creative expression, cultural activities, and connection to other youth and community are recommended. Providing psychosocial support and a context for socioemotional learning is critical. Some youth shared that such personalized attention, characterized by deep and active listening, was key to their transformation."

In the backdrop of the need to open spaces for young people of Nigeria to contribute to peacebuilding, the author spoke to a large number of youths to capture their perspectives. The youth were unanimous in their views that there was need to make conscious efforts to put aside cultural differences with an attitude of tolerance. The youth felt lot of awareness and sensitization programmes needed to be shaped so that they realize that true peace requires a spirit of appreciation and not an attitude of intolerance. "True peace will come only when we stop putting aside our differences and learn to embrace them, they pointed out. 
Given the wide diversity that Nigeria enjoys, the youth felt that it was only when they start appreciating and embrace their differences that they will realise living united in diversity is not a contradiction of terms but rather a state of peace.

The youth opined that peace was what every single person and every state desired. However, it can never be achieved without empathy, understanding, forgiveness, acceptance, tolerance, love, togetherness, unity and harmony, they added. A number of youths who were interviewed talked of promoting empathetic connections to ensure peaceful coexistence. They pointed out, "When there is empathy, there would be understanding and the understanding of selves and situations would lead to peace and unity."

The author organized a focus group discussion on the essence of imbibing nonviolence in one's daily lives to ensure peace in the community. The youth felt by indulging in nonviolent action and making nonviolence a habit, we can promote lot of positive energy around. Meaningful and respectful interactions will be the norm and we will start understanding each other deeply, the youth felt. The youth observed that nonviolence rejects the use of violence and accepts the use of peace instruments to advocate and promote peace.

While the youth accepted that conflicts have been part of life and will always remain, they stressed the importance of forgiveness. When you forget and forgive, you will have peace of mind, they noted. By evolving oneself into an individual who was forgiving in nature, it gives one a chance to build a new world which was full of happiness and joy. "Peace tends to come and spread when we forgive others and our past. Forgiveness allow us to accept others irrespective of their tribe or religion. It strengthens peace and tranquility, unity togetherness," they pointed out.

Another important point the youth pointed out for them to imbibe to become effective peace-builders was to learn the art of accepting each other and his/her religion irrespective of who they are and what the religion is. "Our faith does not matter, what matters is what we want to accomplish in life. When we accept each other, we tend to have more peace and harmony. It brings about the spirit of togetherness and solidarity," they added. Along with the art of acceptance, the youth felt there was need to learn the art of being tolerant towards each other.

Youths can play an active role in fostering peace by forming new programmes of peace builders. In the area of ethnic development, the youths of different ethnic groups can forge links and engage in dialogues between cultural minorities to share values, culture and tradition handed down from generation to generation. Youths in political development can work to end violence and foster peace, engage or join political awareness building, or advocate for reform in bureaucracy to ensure good governance, accountability, transparency and citizenry participation.

In Nigeria, many groups of teenagers and even adults have changed the story of yesterday. They became agents of change, peace builders and peace ambassadors. For instance, in 2017, Search For Common Ground trained 52 youth (a group of Christian and Muslim teenagers, both boys and girls) on peace and conflict resolution. These youth implemented some community initiatives in their various schools and communities. They did community awareness programs on illicit drug abuse, child abuse, peace education, SAY NO to BULLYING, tolerance education etc.

\section{CONCLUSION}

Mahatma Gandhi said, "A small body of determined spirits fired by an unquenchable faith in their mission can alter the course of history."

We are born to live together in peace. We have no right to fight each other. We have no right to destroy the peace and happiness of others. The youth of Nigeria need to muster indomitable courage and as Gandhi had said 'with unquenchable faith in their mission' reach out to all and contribute towards a culture of peace.

\section{REFERENCES}

Ledearch, John Paul 2005. The Moral Imagination: The Art and Soul of Building Peace; Oxford University Press. 
UNESCO. 2013. UNESCO's Programme of Action. Culture of Peace and Nonviolence: A Vision of Action. Paris, UNESCO.

United Nations Development Programme (UNDP) Bureau for Crisis Prevention and Recovery. 2005. Youth and violent conflict in the society: Society and development in crises? A strategic review with a special focus on West Africa. Bureau for Crisis Prevention and Recovery; Available from: $<$ http:// www.unicefinemergencies.com/ downloads/eresource/ docs/Adolescents/Youth\%20 and\%20Violent\%20Conflict\%20 UNDP-BCPR_160.pdf>
Youth, Peace and Security: Insights from Engaged and Disengaged Young Women and Men in Nepal, Niger, Nigeria and Tunisia (2017). Search for Common Ground; October 2017. 
